
3 Research Square
Preprints are preliminary reports that have not undergone peer review.
They should not be considered conclusive, used to inform clinical practice, or referenced by the media as validated information.

\title{
Neuronal Ceroid Lipofuscinosis Treated with Haploidentical Hematopoietic Stem Cell Transplantation Combined with Post-Transplant Cyclophosphamide
}

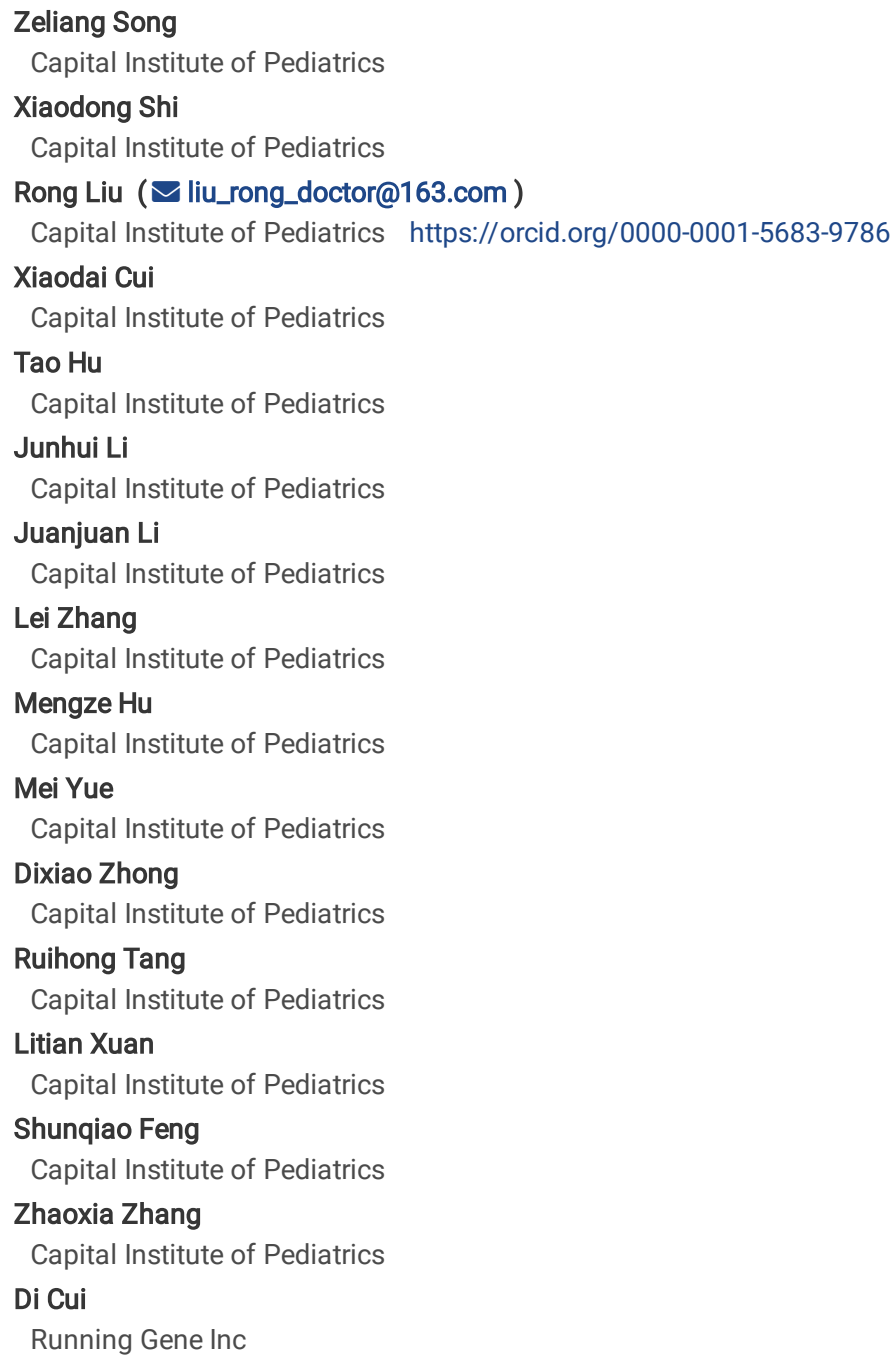

Research

Keywords: neuronal ceroid lipofuscinosis, haploidentical stem cell transplantation, post-transplant cyclophosphamide, haplo-HSCT

Posted Date: September 29th, 2021

DOl: https://doi.org/10.21203/rs.3.rs-927269/v1

License: (9) (7) This work is licensed under a Creative Commons Attribution 4.0 International License. Read Full License 


\section{Abstract}

Background: Neuronal ceroid lipofuscinoses (NCLs) are rare lysosomal storage disorders, characterized by progressive mental retardation and motor developmental regression, and myoclonic seizures. Hematopoietic stem cell transplantation (HSCT) has been suggested to be used in the treatment of lysosomal disorders and brain damage caused by a deficiency of soluble lysosomal enzymes. However, there are no reports on treating NCLs with HSCT in China.Results: From January 2018 to May 2019, we performed haplo-HSCT followed by PT/Cy on 8 NCL pediatric patients. The median age was 4.5 years (range from 2.8 to 7 years). And the donors were their haploidentical HLA-matched parents, as no identically matched donor was found. The median nucleated cell count was $25.37(10-34.41) \times 10^{8} / \mathrm{kg}$ and the median CD34+ count was $13.7(8.95-22) \times 10^{6} / \mathrm{kg}$. Neutrophil reconstitution occurred at 12 days (11-14 days) after transplantation, and median platelet reconstitution time was 12 days (9-14 days) after transplantation. All patients achieved full donor chimerism and did not develop Grade II-IV acute GvHD or chronic GvHD after transplantation. The median follow-up period was 2.2 (1.5-2.6) years. All patients are still alive at present, and develop no severe transplantation-related complications. The mental and motor disorders, myoclonic seizures, and vision loss of all patients continue to progress, but the progression slows down at 12 months after the transplantation.

Conclusion: Observations reported in this study suggest it is safe and efficacy to treat NCLs with haplo-HSCT. Transplantation should be performed as early as possible for the survival quality of pediatric patients.

\section{Background}

Neuronal ceroid lipofuscinoses (NCLs) are rare, inherited lysosomal storage disorders, characterized by progressive mental retardation and motor developmental regression, and myoclonic seizures ${ }^{1}$. Patients develop the disease early, almost in the childhood. Most patients have vision loss, and ultimately die in the early adulthood. The global incidence is $1.3-7.3 / 100,000$ in live births ${ }^{2}$. No epidemiological data in China is currently available and only 30 cases have been reporteduntil now ${ }^{3}$. At present, the therapeutic approaches for NCLs are still mostly experimental and the disease is still considered as incurable. There are few reports on treatment of NCL for HSCT in the previous literature, and the case report has a poor effect after transplantation. However, some literatures reported that the treatment of NCL for HSCT can be tried. At the strong request of parents and approved by the ethics committee of the research center, this study conducted hematopoietic stem cell transplantation in NCL children. After the initial observation was effective, a series of follow-up treatments were carried out for children.

Previously, the NCLs were classified by the onset ages of patients: infantile NCL (INCL), late INCL, juvenile NCL and adult NCL ${ }^{4}$. Patients were usually diagnosed according to the results of skin biopsy, blood enzymology and related protein tests. With the development of next-generation sequencing (NGS), mutations of different genes have been identified to cause NCLs. The NCLs are now classified according to the underlying gene defect. And the genetic analysis was used to help the diagnosis ${ }^{5,6}$. All NCL-related genes locate on autosomes, inheritances of which are autosomal recessive in most cases ${ }^{7-9}$.

When neurological symptoms occur in patients, it is difficult to treat lysosomal storage disorders. Some previous experimental therapies, such as enzyme replacement therapy (ERT), have limited efficiency in improving the pathologies of the central nervous system. Other therapies, such as companion therapy, gene therapy, central nervous system ERT administration and cell therapy, have shown promising effects on the improvement of central nervous system. However, these methods are still in the experimental stage to a large extent. Hematopoietic stem cell transplantation (HSCT) has been suggested to be used in the treatment of lysosomal disorders and brain damage caused by a deficiency of soluble lysosomal enzymes ${ }^{10}$. A probable mechanism of treating adrenoleukodystrophy through HSCT was proposed: the donor-derived monocytes penetrate the blood-brain barrier and differentiate into microglial cells, the enzyme deficiency is improved, and the progression of neuropathy could be stopped ${ }^{11}$. Similarly, HSCT may be able to slow the progression of neuropathy in NCL patients. Allogeneic HSCT (allo-HSCT) from matched siblings is the primary treatment for benign diseases in children. However, most pediatric patients currently do not have a human leukocyte antigen ( $\mathrm{HLA}$ ) fully matched relatives or unrelated donors. Haploidentical parents can be served as alternative donors to provide biological factors to treat the disease. The major representative haploidentical transplantations include granulocyte colony-stimulating factors, antithymocyte globulin and post-transplantation high-dose cyclophosphamide. And a series of studies have shown the successful use of haploidentical donors in the treatment of hematologic malignancies and severe aplastic anemia ${ }^{12-14}$. The failure of allo-HSCT limits its application in the treatment of benign diseases, especially the inherited metabolic disorders, the transplantation failure rate of which is higher than $20 \%{ }^{15}$. Full donor chimerism may fail after the transplantations, and patients may develop graft-versus-host disease (GvHD). The haploidentical HSCT fails and the disease could not be cured. Thus, it is significant to prevent patients from GvHD after the haploidentical HSCT. Compared with the conventional T-cell depletion method, the post-transplant cyclophosphamide (PT/Cy) regimen used currently is safer, and induces fewer complications ${ }^{16}$. It enables rapid immune reconstitution in pediatric patients, expanding the pool of HSCT donors ${ }^{17}$. This method has been successfully used to treat some lysosomal storage diseases (such as Mucopolysaccharidosis18) with safety and efficiency. However, PT/Cy has not been reported to treat patients with NCLs previously.

In this study, we firstly performed allo-HSCT followed by the modified PT/Cy regimen on eight NCLs pediatric patients. All patients are still alive at present, and develop no severe transplantation-related complications. The progression of symptoms caused by the disease began to slow down at 12 months after the transplantation. Observations reported in this study suggest the potential to treat NCLs with haplo-HSCT and PT/Cy.

\section{Methods}

\section{Patients}

This study involved NCL pediatric patients who underwent allo-HSCT at the Affiliated Children's Hospital of Capital Institute of Pediatrics from January 2018 to May 2019. A combination of medical histories, clinical features and genetic analyses was used for the diagnosis of all patients. A written consent form for 
allo-HSCT was obtained from the patient's guardian, which was then reviewed and approved by the ethics committee before the procedure.

\section{Donor selection}

Select non-carrier sibling donors or unrelated donors, whose umbilical cord blood is identically matched: intermediate resolution type of $6 / 6$ for non-carrier sibling and high resolution type of 10/10 for unrelated donors. If no complete HLA-matched donors were found, selected HLA-matched haploidentical

father/mother as the donor.

\section{Haploidentical HSCT}

Before the haploidentical HSCT, a combination of rabbit anti-human thymocyte immunoglobulin, cyclophosphamide, fludarabine and busulfan (ATG + CTX + Flu + Bu) was given to the all eight patients, with the specific details: $2.5 \mathrm{mg} / \mathrm{kg} / \mathrm{d}$ ATG from 9 to 7 days before the transplantation (total dose: $7.5 \mathrm{mg} / \mathrm{kg}$ ); $14.5 \mathrm{mg} / \mathrm{kg} / \mathrm{d}$ CTX from 6 to 5 days before the transplantation (total duration: 2 days, total dose: $29 \mathrm{mg} / \mathrm{kg}$ ); $35 \mathrm{mg} / \mathrm{m}^{2} / \mathrm{d} \mathrm{Flu} \mathrm{from} 6$ to 2 days before the transplantation (total duration: 5 days, total dose: $165 \mathrm{mg} / \mathrm{m}^{2}$ ); and $4 \mathrm{mg} / \mathrm{kg} / \mathrm{d}$ Bu was administered intravenously from 5 to 2 days before the transplantation (total duration: 4 days, total dose: $12 \mathrm{mg} / \mathrm{kg}$ ). Meanwhile, subcutaneous injection of $5 \mu \mathrm{g} / \mathrm{kg} / \mathrm{d}$ granulocyte colony-stimulating factor (G-CSF) was administered to all donors for 5 continuous days. On the fifth day, bone marrow blood was collected, and then used to isolate the peripheral blood stem cells using the Cobe Spectra apheresis machine (Terumo BCT Inc., USA) or COM.TEC apheresis machine.

The G-CSF-mobilized bone marrow and peripheral blood stem cells collected from the donor were directly transfused through a central vein.

On the fifth day after the transplantation, $500-600 \mathrm{mg} / \mathrm{m}^{2} / \mathrm{d}$ mycophenolate mofetil was administered orally every 12 hours for $5-28$ days after transplantation. On the same day, $0.01-0.03 \mathrm{mg} / \mathrm{kg} / \mathrm{d}$ tacrolimus was administered as a 24-hour continuous intravenous infusion with a pump. The plasma drug concentration was monitored, and the medicine dose was adjusted to maintain the trough concentration at $4-6 \mathrm{ng} / \mathrm{mL}$ for 25 days. Then tacrolimus was switched from intravenous to oral administration and was gradually reduced for the next three months until discontinuation in the sixth months after the transplantation. In addition, all pediatric patients received $5 \mu \mathrm{g} / \mathrm{kg} / \mathrm{d}$ G-CSF since the sixth day after transplantation, until the granulocyte reconstitution was finished. The medicine order was shown in Fig. 1.

After the transplantation, the trends of cytokines, total lymphocyte count, and activated T-lymphocytes in pediatric patients were also dynamically monitored. Peripheral blood chimerism was monitored at $0.5,1,3,6$, and 12 months after the transplantation. Short tandem repeat DNA sequencing was used to detect donor chimerism in patients after hematopoietic reconstitution. Complete transplantation was defined as reconstitution of $95.0 \%$ and above donor component reconstruction.

\section{Relevant supportive treatment}

During the pre-treatment, sufficient hydration and urine alkalinization were carried out. After the pre-transplantation examination and drug bath, the pediatric patients were sent to a sterile laminar flow room for subclavian venous catheter insertion. Routine prophylaxis for Pneumocystis jiroveci, bacteria, fungi, virus, and other pathogenic microorganisms were performed. If infection was discovered, empiric broad-spectrum antibiotics were given. Then, the adjustments were made based on pathology results. During transplantation, if hemoglobin concentration was lower than $80 \mathrm{~g} / \mathrm{L}$ and platelet count was lower than $20 \times 10^{9} / \mathrm{L}$, matched irradiated blood products were given as transfusion for supportive treatment. After transplantation, routine intravenous injection of immunoglobulin $(+1,+11,+21,+31 \mathrm{~d})$ and oral acyclovir were used for cytomegalovirus (CMV) prophylaxis. Low-molecular-weight heparin, alprostadil, and ursodiol were used as prophylaxis for veno-occlusive disease occlusive disease until 28 days after transplantation.

\section{Definitions of related diagnoses}

(1) Granulocyte reconstitution: Absolute peripheral blood granulocyte count $\geq 0.5 \times 10^{9} / \mathrm{L}$ for 3 continuous days. Platelet reconstitution: Platelet count $\geq$ $20 \times 10^{9} /$ L for $^{7}$ continuous daysm ${ }^{19}$. (2) Acute GvHD and chronic GvHD: Diagnosis and grading were referenced from existing studies ${ }^{20}$. Grading was based on skin (rash area), gastrointestinal tract (number of daily diarrhea episodes), and liver (total bilirubin level) findings. Then, an overall grade was obtained based on the degree of injury to each organ from Grade I to IV. Grade III-IV acute GvHD was defined as severe GvHD. Chronic GvHD was graded according to the US National Institutes of Health ${ }^{21}$. (3) CMV viremia and Epstein-Barr virus (EBV) viremia: Plasma CMV-DNA >I copy/mL for 2 continuous measurements was defined as CMV viremia; plasma EBV-DNA > 500 copies $/ \mathrm{mL}$ for 2 continuous measurements was defined as EBV viremia ${ }^{22}$.

\section{Results \\ Clinical Presentations}

Eight pediatric patients who had NCLs and underwent allo-HSCT were enrolled in this study, of which two were male and six were female (Table 1). All patients except patient 2 had mental and motor disorders. They presented with myoclonic seizures and/or vision loss, and received 1-4 oral anticonvulsants. For patient 2, she only presented with dysarthria and had the youngest age when diagnosed (2.6 years old, median age at diagnosis of 4.5 years). Patients 2 and 3 were full sisters. Patient 3 was diagnosed with CLN6, then patient 2 was suspected to have the same disease. Cranial magnetic resonance imaging (MRI) and genetic analysis were performed and a definitive diagnosis of CLN6 was confirmed. All pediatric patients showed abnormal cranial MRI results (Fig. 2). 
Table 1

Clinical data of pediatric patients who underwent transplantation.

\begin{tabular}{|c|c|c|c|c|c|c|c|c|}
\hline Patient & Sex & $\begin{array}{l}\text { Height } \\
\text { (cm)/Weight } \\
(\mathrm{kg})\end{array}$ & $\begin{array}{l}\text { Age at } \\
\text { diagnosis/ } \\
\text { transplantation } \\
\text { (years) }\end{array}$ & $\begin{array}{l}\text { Clinical } \\
\text { presentation }\end{array}$ & $\begin{array}{l}\text { Imaging } \\
\text { presentation }\end{array}$ & $\begin{array}{l}\text { Enzymology } \\
\text { of TTP1 } \\
(\mathrm{nmol} / \mathrm{g} / \mathrm{min})\end{array}$ & Genetic analysis & $\begin{array}{l}\text { HLA } \\
\text { relationship }\end{array}$ \\
\hline 1 & $\mathrm{~F}$ & $128 / 16.2$ & $6.1 / 7.4$ & $\begin{array}{l}\text { Convulsions, } \\
\text { dysarthria, } \\
\text { blurred vision }\end{array}$ & $\begin{array}{l}\text { Cerebral atrophy, } \\
\text { pronounced at } \\
\text { bilateral cerebellum }\end{array}$ & - & $\begin{array}{l}\text { MFSD8 (c. } 553 \mathrm{G}>\mathrm{A}, \\
\text { p.V185l; c. } 1391 \mathrm{C}>\mathrm{T}, \\
\text { p.A464V) }\end{array}$ & $\begin{array}{l}6 / 12 \\
\text { (father) }\end{array}$ \\
\hline 2 & $\mathrm{~F}$ & $95 / 13.9$ & $2.6 / 2.8$ & Dysarthria & $\begin{array}{l}\text { Possible } \\
\text { demyelination } \\
\text { lesions }\end{array}$ & - & $\begin{array}{l}\text { CLN6 (c. 184C > T, p.R62C; } \\
\text { c. } 158 \mathrm{~T}>\mathrm{C}, \mathrm{p} . \mathrm{L} 53 \mathrm{P})\end{array}$ & $\begin{array}{l}\text { 10/12 } \\
\text { (father) }\end{array}$ \\
\hline 3 & $\mathrm{~F}$ & $105 / 17$ & $3.9 / 4.8$ & $\begin{array}{l}\text { Convulsions, } \\
\text { dysarthria }\end{array}$ & Cerebral atrophy, & - & $\begin{array}{l}\text { CLN6 (c. } 184 C \text { > T, p.R62C; } \\
\text { c.158T > C, p.L53P) }\end{array}$ & $\begin{array}{l}10 / 12 \\
\text { (father) }\end{array}$ \\
\hline 4 & $\mathrm{~F}$ & $114 / 14.3$ & $5 / 5.3$ & $\begin{array}{l}\text { Convulsions, } \\
\text { dysarthria, } \\
\text { unstable gait }\end{array}$ & Cerebral atrophy, & 26.5 & $\begin{array}{l}\text { TPP1 (c.1361C > A, } \\
\text { p.A454E; c.1222_1224del, } \\
\text { p.S408del) }\end{array}$ & $\begin{array}{l}7 / 12 \\
\text { (father) }\end{array}$ \\
\hline 5 & M & $105 / 15$ & $4.1 / 4.8$ & $\begin{array}{l}\text { Blurred vision, } \\
\text { unstable gait }\end{array}$ & $\begin{array}{l}\text { Cerebral atrophy, } \\
\text { pronounced at } \\
\text { bilateral cerebellum }\end{array}$ & - & $\begin{array}{l}\text { MFSD8 (c. } 1102 \mathrm{G}>\mathrm{C} \\
\text { p.D368H; c.103C > T, } \\
\text { p.R35X) }\end{array}$ & $\begin{array}{l}\text { 6/12 } \\
\text { (father) }\end{array}$ \\
\hline 6 & $M$ & $98 / 14$ & $4.5 / 5.2$ & $\begin{array}{l}\text { Dysarthria, } \\
\text { unstable gait, } \\
\text { limb tremors }\end{array}$ & $\begin{array}{l}\text { Cerebral atrophy, } \\
\text { pronounced at } \\
\text { bilateral cerebellum }\end{array}$ & - & $\begin{array}{l}\text { MFSD8 (c. } 416 \mathrm{G}>\mathrm{A}, \\
\text { p.R139H; c.114delG, } \\
\text { p.E381Kf*33) }\end{array}$ & $\begin{array}{l}8 / 12 \\
\text { (Mother) }\end{array}$ \\
\hline 7 & $\mathrm{~F}$ & $120 / 17.5$ & $4.8 / 5.3$ & $\begin{array}{l}\text { Dysarthria, } \\
\text { unstable gait, } \\
\text { limb tremors }\end{array}$ & Cerebral atrophy, & - & $\begin{array}{l}\text { CLN6 (c.794_c.796delCCT, } \\
\text { p.S265_F266delinsF; } \\
\text { c.826T > G, p.W276G) }\end{array}$ & $\begin{array}{l}\text { 6/12 } \\
\text { (Mother) }\end{array}$ \\
\hline 8 & $\mathrm{~F}$ & $110 / 18.5$ & $4 / 5.5$ & $\begin{array}{l}\text { Convulsions, } \\
\text { limb tremors }\end{array}$ & $\begin{array}{l}\text { Cerebral atrophy, } \\
\text { pronounced at } \\
\text { bilateral cerebellum }\end{array}$ & 2.5 & $\begin{array}{l}\text { TPP1 (c. } 1417 \mathrm{G}>\mathrm{A}, \\
\text { p.G473R; c.1613C >A, } \\
\text { p.S538Y) }\end{array}$ & $\begin{array}{l}8 / 12 \\
\text { (father) }\end{array}$ \\
\hline
\end{tabular}

\section{Haploidentical HSCT}

No identically matched donor was found in all eight patients, so they finally received allo-HSCT from haploidentical HLA-matched parent donors (Table 1). All donors were healthy. And the median age of the donors was 34 (31-48 years). The donors of six pediatric patients were fathers and the donors of two pediatric patients were mothers. Three donors were haploidentical and HLA-matched at 6/12 sites, two donors matched at 10/12 sites, one donor matched at $7 / 12$ sites, and two donors matched at $6 / 12$ sites.

G-CSF mobilized bone marrow and peripheral blood were used as sources of stem cells for the patients. The median nucleated cell count used for infusion was $25.37(10-34.41) \times 10^{8} / \mathrm{kg}$ and median CD34 ${ }^{+}$count was $13.7(8.95-22) \times 10^{6} / \mathrm{kg}$. The results are shown in Table 2 .

Table 2

Transplantation results of eight pediatric patients

\begin{tabular}{|c|c|c|c|c|c|c|c|c|}
\hline \multirow[t]{2}{*}{ Patient } & \multicolumn{2}{|c|}{ Grafted cell count } & \multirow{2}{*}{$\begin{array}{l}\text { Neutrophil } \\
\text { Reconstitution } \\
\text { duration (d) }\end{array}$} & \multirow{2}{*}{$\begin{array}{l}\text { Platelet } \\
\text { Reconstitution } \\
\text { duration (d) }\end{array}$} & \multirow{2}{*}{$\begin{array}{l}\text { 30D post- } \\
\text { transplantation } \\
\text { Chimerism (\%) }\end{array}$} & \multirow{2}{*}{$\begin{array}{l}\text { Acute/chronic } \\
\text { GvHD }\end{array}$} & \multirow{2}{*}{$\begin{array}{l}\text { CMV/ EBV } \\
\text { activation } \\
\text { Time (d) }\end{array}$} & \multirow{2}{*}{$\begin{array}{l}\text { Follow-up period } \\
\text { (months) }\end{array}$} \\
\hline & $\begin{array}{l}\text { Monocyte } \\
\text { count } \\
\left(\times 10^{8} / \mathrm{kg}\right)\end{array}$ & $\begin{array}{l}{\mathrm{CD} 34^{+}}_{\text {count }} \\
\left(\times 10^{6} / \mathrm{kg}\right)\end{array}$ & & & & & & \\
\hline 1 & 10 & 8.95 & 14 & 14 & 99 & - & $+15 /-$ & 3 \\
\hline 2 & 31.78 & 15.82 & 12 & 13 & 99 & - & $+19 /-$ & 11 \\
\hline 3 & 28.16 & 14.2 & 12 & 12 & 99 & - & $+21 /-$ & 11 \\
\hline 4 & 34.41 & 10.02 & 12 & 12 & 99 & - & $+27 /+27$ & 12 \\
\hline 5 & 20.65 & 12.94 & 13 & 11 & 99 & - & $-/-$ & 14 \\
\hline 6 & 23.45 & 10.8 & 12 & 11 & 99 & - & - & 15 \\
\hline 7 & 27 & 22 & 11 & 9 & 99 & - & $-/-$ & 16 \\
\hline 8 & 27.51 & 15.22 & 13 & 11 & 99 & - & $-/-$ & 19 \\
\hline
\end{tabular}

After transplantation, the median neutrophil reconstitution time was 12 days (11-14 days) and the median platelet reconstitution time was 12 days (9-14 days). Full donor chimerism (>99\%) was achieved in T, B, NK cells at one month after transplantation in all patients. No acute or chronic GvHD appeared. After the granulocyte reconstitution, all pediatric patients showed agile eye expressions, increased speech and limb movements, and significantly improved myoclonus, which were maintained for 2-4 weeks. Five of these eight pediatric patients developed CMV viremia 2-4 weeks after the transplantation, which 
improved after reducing the dose of immunosuppressive agents and adding ganciclovir or foscarnet sodium to the therapy. The viremia persisted for two weeks. One patient developed EBV viremia 27 days after the transplantation and tested negatively after one week of dose reduction of immunosuppressants. All the eight pediatric patients did not develop oral infection, intestinal infection, lung infection, hemorrhagic cystitis, or other complications (Table 3).

Table 3

Clinical data of patients with NCL after HSCT (Pre/After)

\begin{tabular}{|c|c|c|c|c|c|c|c|c|c|c|c|}
\hline Patient & $\begin{array}{l}\text { Upper } \\
\text { airway } \\
\text { blockage }\end{array}$ & Dysphagia & $\begin{array}{l}\text { Vision } \\
\text { loss }\end{array}$ & $\begin{array}{l}\text { Hearing } \\
\text { loss }\end{array}$ & $\begin{array}{l}\text { Myoclonic } \\
\text { seizures }\end{array}$ & $\begin{array}{l}\text { Mental } \\
\text { retardation }\end{array}$ & $\begin{array}{l}\text { Unstable } \\
\text { gait }\end{array}$ & $\begin{array}{l}\text { Language } \\
\text { impairment }\end{array}$ & $\begin{array}{l}\text { Anticonvulsant } \\
\text { drug }\end{array}$ & $\begin{array}{l}\text { Cranial } \\
\text { imaging } \\
\text { abnormalities }\end{array}$ & $A D L$ \\
\hline 1 & $\mathrm{~N} / \mathrm{N}$ & $\mathrm{N} / \mathrm{N}$ & $\mathrm{Y} / \mathrm{Y}$ & $\mathrm{N} / \mathrm{N}$ & $\mathrm{Y} / \mathrm{Y}$ & $\mathrm{Y} / \mathrm{Y}$ & $\mathrm{Y} / \mathrm{Y}$ & $\mathrm{Y} / \mathrm{Y}$ & $\mathrm{Y} / \mathrm{Y}$ & $\mathrm{Y} / \mathrm{Y}$ & $80 / 80$ \\
\hline 2 & $\mathrm{~N} / \mathrm{N}$ & $\mathrm{N} / \mathrm{N}$ & $\mathrm{N} / \mathrm{N}$ & $\mathrm{N} / \mathrm{N}$ & $\mathrm{N} / \mathrm{N}$ & $\mathrm{N} / \mathrm{N}$ & $\mathrm{N} / \mathrm{N}$ & $\mathrm{Y} / \mathrm{Y}$ & $\mathrm{N} / \mathrm{N}$ & $\mathrm{Y} / \mathrm{Y}$ & $-/-$ \\
\hline 3 & $\mathrm{~N} / \mathrm{N}$ & $\mathrm{N} / \mathrm{N}$ & $\mathrm{N} / \mathrm{N}$ & $\mathrm{N} / \mathrm{N}$ & $\mathrm{Y} / \mathrm{Y}$ & $\mathrm{Y} / \mathrm{Y}$ & $\mathrm{Y} / \mathrm{Y}$ & $\mathrm{Y} / \mathrm{Y}$ & $\mathrm{Y} / \mathrm{Y}$ & $\mathrm{Y} / \mathrm{Y}$ & $50 / 50$ \\
\hline 4 & $\mathrm{~N} / \mathrm{N}$ & $\mathrm{Y} / \mathrm{Y}$ & $\mathrm{N} / \mathrm{N}$ & $\mathrm{N} / \mathrm{N}$ & $\mathrm{Y} / \mathrm{Y}$ & $Y / Y$ & $\mathrm{Y} / \mathrm{Y}$ & $\mathrm{Y} / \mathrm{Y}$ & $\mathrm{Y} / \mathrm{Y}$ & $\mathrm{Y} / \mathrm{Y}$ & $5 / 5$ \\
\hline 5 & $\mathrm{~N} / \mathrm{N}$ & $\mathrm{N} / \mathrm{N}$ & $Y / Y$ & $\mathrm{~N} / \mathrm{N}$ & $\mathrm{Y} / \mathrm{Y}$ & $\mathrm{Y} / \mathrm{Y}$ & $\mathrm{Y} / \mathrm{Y}$ & $\mathrm{Y} / \mathrm{Y}$ & $\mathrm{Y} / \mathrm{Y}$ & $\mathrm{Y} / \mathrm{Y}$ & $50 / 50$ \\
\hline 6 & $\mathrm{~N} / \mathrm{N}$ & $\mathrm{N} / \mathrm{N}$ & $\mathrm{Y} / \mathrm{Y}$ & $\mathrm{N} / \mathrm{N}$ & $Y / Y$ & $Y / Y$ & $\mathrm{Y} / \mathrm{Y}$ & $\mathrm{Y} / \mathrm{Y}$ & $Y / Y$ & $\mathrm{Y} / \mathrm{Y}$ & $60 / 60$ \\
\hline 7 & $\mathrm{~N} / \mathrm{N}$ & $\mathrm{N} / \mathrm{N}$ & $\mathrm{N} / \mathrm{N}$ & $\mathrm{N} / \mathrm{N}$ & $\mathrm{Y} / \mathrm{Y}$ & $\mathrm{Y} / \mathrm{Y}$ & $\mathrm{Y} / \mathrm{Y}$ & $\mathrm{Y} / \mathrm{Y}$ & $\mathrm{Y} / \mathrm{Y}$ & $\mathrm{Y} / \mathrm{Y}$ & $55 / 55$ \\
\hline 8 & $\mathrm{~N} / \mathrm{N}$ & $\mathrm{N} / \mathrm{N}$ & $\mathrm{N} / \mathrm{N}$ & $\mathrm{N} / \mathrm{N}$ & $\mathrm{Y} / \mathrm{Y}$ & $\mathrm{Y} / \mathrm{Y}$ & $\mathrm{Y} / \mathrm{Y}$ & $\mathrm{Y} / \mathrm{Y}$ & $\mathrm{Y} / \mathrm{Y}$ & $\mathrm{Y} / \mathrm{Y}$ & $45 / 45$ \\
\hline
\end{tabular}

All data was obtained at 1 month before transplantation and recent results after transplantation.

N, NO; Y, YES; ADL, activity of daily living (using the Barthel index of $A D L$ ).

\section{Post-transplantation follow-up}

Until September 30th, 2020, all patients (100\%) had non-event survival, a median follow-up duration of 2.2 years (1.5-2.6 years). All patients achieved full donor chimerism one month after the transplantation, and the DNA fingerprints of seven pediatric patients who survived more than one year showed complete donor chimerism during follow-up. The youngest patient ( 2.6 years old) had dysarthria prior to transplantation, while the symptoms did not progress after transplantation. As the patient was prone to thrombosis, femoral vein thrombosis occurred after insertion of a central venous catheter in the left femoral vein. At present, the femoral vein thrombosis still persists, causing unstable gait with no other symptoms noted. Mental and motor deficits in other pediatric patients began to slow down 9-12 months after the transplantation, but the regression persisted. Myoclonic seizures and vision loss gradually improved after transplantation, and the dose of anticonvulsant medications was gradually reduced. The data is collected and shown in Table 3.

\section{Discussion}

At present, the treatment of pediatric patients suffering from lysosomal disorders with neurological symptoms is facing major challenges. Many treatments have been tried in China. However, most treatments are still experimental, and show limited efficacy. An ERT regimen used in treating NCL2 has been established, but the efficacy has not been proven, and drugs used in the treatment are not available in China. There are no effective methods of controlling or improving the condition of NCLs pediatric patients. Only supportive treatments could have been given to the patients. HSCT has been recommended as the treatment of lysosomal disorder with brain damage caused by a soluble lysosomal enzymes deficiency, but no related reports are available in China. AlloHSCT using cells from matched sibling donors is the primary treatment of benign diseases in children. However, it is difficult to obtain suitable donors. And GvHD remains a major obstacle to the success of HSCT. Compared with conventional T-cell depletion methods, the PT/Cy regimen used in recent years is more cost-effective and has fewer complications. It allows pediatric patients to rapidly undergo immune reconstitution, expanding the pool of HSCT donors.

The prevalence of haplo-HSCT is increasing year-by-year in China. However, there are no reports on treating NCLs with HSCT in China. The cases of using PT/Cy regimen to treat benign diseases in Chinese pediatric patients are rare. And the treatment of HSCT combined with PT/Cy still in the clinical trial phase abroad. We are the first to perform this treatment in NCLs patients. The HSC transplantation in our eight patients was successful, with granulocytes and platelets being successfully reconstituted. Complete chimerism was achieved. No acute/chronic GvHD occurred. The hematopoietic and immune reconstitution were ultimately achieved. These results indicate a satisfactory transplantation result. Genetic and cranial imaging abnormalities were observed in patient 2, who presents no disease-related symptoms. The delay of disease progression observed in patient 2 suggests that early transplantation may be beneficial in these patients. Some patients developed infections during the period of virus activation and granulocytopenia. Therefore, when using this regimen in the future, donor selection and physical examination must be performed prior to the transplantation to prevent latent infections. We recommend the post-transplantation monitoring of CMV activity in the recipients, and prompt administration of ganciclovir antiviral treatment to adequately protect the heart, liver, spleen, and major organs. Empiric broad-spectrum antibiotics must be given to pediatric patients with persistent fever over $38.5^{\circ} \mathrm{C}$, and adjusted after pathology results are obtained, in order to control the infection as soon as possible to ensure a good transplantation outcome and patient survival.

No symptoms occurred except for the youngest patient (2.6 years old) who had dysarthria before the transplantation and the dysarthria symptoms did not progress after the transplantation. At the time of follow-up, the patient is 3 years and 8 months old. Compared with her full elder sister (patient 3 ), this patient had convulsions and experienced falls when standing up, so anticonvulsant therapy was gradually increased. The mental and motor disorders continued to develop in other pediatric patients, but the progression slowed down at 9-12 months after the transplantation. Myoclonic seizures and vision loss gradually improved after the transplantation, and the dose of anticonvulsants was gradually reduced. To date, all eight pediatric patients have achieved rapidly complete donor chimerism. Currently, seven patients maintained full donor chimerism at follow-up after more than one year. The overall survival rate is 
encouraging. Based on our preliminary observations, haploidentical HSCT is safe and feasible to treat NCLs. Further follow-up observations are needed to assess the long-term efficacy of this method.

The results of haploidentical HSCT reported here show significantly low toxicity and high implantation rates. The preliminary follow-up data suggests that donor chimerism was stable and persistent. Further long-term follow-up and extensive neurocognitive studies are needed to determine the affects and efficacy of transplantation on the natural progression of NCLs. And the consideration of how to rapidly reconstitute microglial cells derived from the donor in the central nervous system is also needed to achieve disease stabilization within a short period after HSCT.

In summary, high-dose PT/Cy can be used after the haplo-HSCT to successfully treat NCLs in children and prevent GvHD. Early transplantation shows good results with control of acute/chronic GvHD and major transplantation-related events. In addition, immunosuppressants are gradually discontinued, and immune reconstitution occurs rapidly. This method further expands the allo-HSCT donor pool, making it a viable option for patients without suitable donors. However, the efficacy of HSCT for NCLs remains poor. More clinical trials are required to investigate the safety for the treatment of NCLs.

\section{Declarations}

Ethics Approval and Consent for Participation and Publication

This study was approved by the research ethics committee of the Children's Hospital of Capital Institute of Pediatrics (Identifier: SHERLLM2020015). The guardians of the pediatric patients also signed a written informed consent forms for the investigation and publication of articles.

\section{Availability of Data and Materials}

The datasets analyzed during the current study are not publicly available because the data is used by another undergoing study but are available from the corresponding author on reasonable request.

\section{Conflicts of Interest}

The authors declare that the research was conducted in the absence of any other commercial or financial relationships that could be construed as a potential

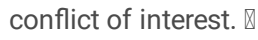

\section{Funding}

This research received no external funding.

\section{Authors' Contributions}

As the principal investigator, Rong Liu had full access to all data in this study, and is responsible for the integrity and authenticity of the data. The study concept and design were made by Zeliang Song, Rong Liu, Xiaodai Cui and Xiaodong Shi. Data was collected and analyzed by Tao Hu, Junhui Li, Juanjuan Li, Lei Zhang, Mengze Hu, Mei Yue, Dixiao Zhong, Ruihong Tang, Litian Xuan, Shunqiao Feng, Zhaoxia Zhang. Zeliang Song drafted the manuscript. Di Cui critically revised the manuscript. All authors approved the final manuscript as submitted and agree to be accountable for all aspects of the work. All processes were completed under the supervision of Rong Liu.

\section{Acknowledgments}

We thank the patient and her family for participation and cooperation.

\section{References}

1. Groh J, Berve K, Martini R. Fingolimod and Teriflunomide Attenuate Neurodegeneration in Mouse Models of Neuronal Ceroid Lipofuscinosis. Mol Ther 2017; 25(8): 1889-99. e-pub ahead of print 2017/05/17; doi:10.1016/j.ymthe.2017.04.021.

2. Mink JW, Augustine EF, Adams HR, Marshall FJ, Kwon JM. Classification and natural history of the neuronal ceroid lipofuscinoses. J Child Neurol. 2013;28(9):1101-5. doi:10.1177/0883073813494268. e-pub ahead of print 2013/07/11.

3. Ren SC, Gao BQ, Wang YJ, Wu XJ, Tian ZX, Sun YL. Clinical, genetic and pathological features of neuronal ceroid lipofuscinosis in 5 Chinese patients. Zhonghua Yi Xue Za Zhi 2016; 96(43): 3504-3507. e-pub ahead of print 2016/12/03; doi: 10.3760/cma.j.issn.0376-2491.2016.43.013.

4. Haltia M. The neuronal ceroid-lipofuscinoses: from past to present. Biochimica et biophysica acta 2006; 1762(10): 850-856. e-pub ahead of print 2006/08/16; doi: 10.1016/j.bbadis.2006.06.010.

5. Crystal RG, Sondhi D, Hackett NR, Kaminsky SM, Worgall S, Stieg P, et al. Clinical protocol. Administration of a replication-deficient adeno-associated virus gene transfer vector expressing the human CLN2 cDNA to the brain of children with late infantile neuronal ceroid lipofuscinosis. Hum Gene Ther. 2004;15(11):1131-54. doi:10.1089/hum.2004.15.1131. e-pub ahead of print 2004/12/22.

6. Sleat DE, Gin RM, Sohar I, Wisniewski K, Sklower-Brooks S, Pullarkat RK, et al. Mutational analysis of the defective protease in classic late-infantile neuronal ceroid lipofuscinosis, a neurodegenerative lysosomal storage disorder. Am J Hum Genet. 1999;64(6):1511-23. doi:10.1086/302427. e-pub ahead of print 1999/05/20. 
7. Radke J, Stenzel W, Goebel HH. Human NCL, Neuropathology. Biochimica et biophysica acta 2015; 1852 (10 Pt B): 2262-2266. e-pub ahead of print 2015/05/20; doi: 10.1016/j.bbadis.2015.05.007.

8. Patterson M, Johnson W. Lysosomal and other storage diseases. In: Rowland L, Pedley T, editors. Merritt's Neurology. 12th ed. New York: edn. Lippincott WiHiams \& Wilkins; 2010. pp. 615-32.

9. Goebel HH, Zeman W, Pilz H. Significance of muscle biopsies in neuronal ceroid-lipofuscinoses. Journal of neurology, neurosurgery, and psychiatry 1975; 38(10): 985-993. e-pub ahead of print 1975/10/01; doi: 10.1136/jnnp.38.10.985.

10. Boelens JJ, Orchard PJ, Wynn RF. Transplantation in inborn errors of metabolism: current considerations and future perspectives. British journal of haematology 2014; 167(3): 293-303. e-pub ahead of print 2014/07/31; doi: 10.1111/bjh.13059.

11. Mahmood A, Raymond GV, Dubey P, Peters C, Moser HW. Survival analysis of haematopoietic cell transplantation for childhood cerebral X-linked adrenoleukodystrophy: a comparison study. The Lancet. Neurology 2007; 6(8): 687-692. e-pub ahead of print 2007/07/10; doi: 10.1016/s14744422(07)70177-1.

12. Wang Y, Chang YJ, Xu LP, Liu KY, Liu DH, Zhang XH, et al. Who is the best donor for a related HLA haplotype-mismatched transplant? Blood 2014; 124(6): 843-850. e-pub ahead of print 2014/06/12; doi: 10.1182/blood-2014-03-563130.

13. Xu LP, Xu ZL, Wang FR, Mo XD, Han TT, Han W, et al. Unmanipulated haploidentical transplantation conditioning with busulfan, cyclophosphamide and anti-thymoglobulin for adult severe aplastic anaemia. Bone Marrow Transplant 2018; 53(2): 188-92. e-pub ahead of print 2018/01/16; doi:10.1038/bmt.2017.237.

14. Bashey A, Zhang X, Sizemore CA, Manion K, Brown S, Holland HK, et al. T-cell-replete HLA-haploidentical hematopoietic transplantation for hematologic malignancies using post-transplantation cyclophosphamide results in outcomes equivalent to those of contemporaneous HLA-matched related and unrelated donor transplantation. Journal of clinical oncology: official journal of the American Society of Clinical Oncology. 2013;31(10):1310-6. doi:10.1200/jco.2012.44.3523. e-pub ahead of print 2013/02/21.

15. Chen Y, Xu L, Zhang X, Chen H, Wang F, Liu K, et al. Busulfan, Fludarabine, and Cyclophosphamide (BFC) conditioning allowed stable engraftment after haplo-identical allogeneic stem cell transplantation in children with adrenoleukodystrophy and mucopolysaccharidosis. Bone Marrow Transplant. 2018;53(6):770-3.

16. Rashidi A, Hamadani M, Zhang M, Wang H, Abdel-Azim H, Aljurf M, et al. Outcomes of haploidentical vs matched sibling transplantation for acute myeloid leukemia in first complete remission. Blood Adv. 2019;3(12):1826-36.

17. Gu Z, Wang L, Yuan L, Huang W, Li M, Guan L, et al. Similar outcomes after haploidentical transplantation with post-transplant cyclophosphamide versus HLA-matched transplantation: a meta-analysis of case-control studies. Oncotarget. 2017;8(38):63574-86.

18. Yue Y, Song Z, Li J, Feng S, Liu R, Shi X. Posttransplant Cyclophosphamide for HLA-haploidentical Transplantation in Patients With Mucopolysaccharidosis. J Pediatr Hematol Oncol. 2018;40(6):e350-4.

19. Gao L, Zhang Y, Hu B, Liu J, Kong P, Lou S, et al. Phase II Multicenter, Randomized, Double-Blind Controlled Study of Efficacy and Safety of Umbilical CordDerived Mesenchymal Stromal Cells in the Prophylaxis of Chronic Graft-Versus-Host Disease After HLA-Haploidentical Stem-Cell Transplantation. Journal of clinical oncology: official journal of the American Society of Clinical Oncology. 2016;34(24):2843-50. doi:10.1200/jco.2015.65.3642. e-pub ahead of print 2016/07/13.

20. Przepiorka D, Weisdorf D, Martin P, Klingemann HG, Beatty P, Hows J, et al. 1994 Consensus Conference on Acute GVHD Grading. Bone Marrow Transplant 1995; 15(6): 825-828. e-pub ahead of print 1995/06/01.

21. Martin PJ, Lee SJ, Przepiorka D, Horowitz MM, Koreth J, Vogelsang GB, et al. National Institutes of Health Consensus Development Project on Criteria for Clinical Trials in Chronic Graft-versus-Host Disease: VI. The 2014 Clinical Trial Design Working Group Report. Biol Blood Marrow Transplant. 2015;21(8):1343-59. doi:10.1016/j.bbmt.2015.05.004. e-pub ahead of print 2015/05/20.

22. Xu LP, Liu DH, Liu KY, Zhang CL, Wang FR, Wang JZ, et al. [The efficacy and safety of rituximab in treatment of Epstein-Barr virus disease post allogeneic hematopoietic stem-cell transplantation]. Zhonghua Nei Ke Za Zhi. 2012;51(12):966-70. e-pub ahead of print 2013/01/19.

\section{Figures}




\section{Haplo-HSCT in NCL}

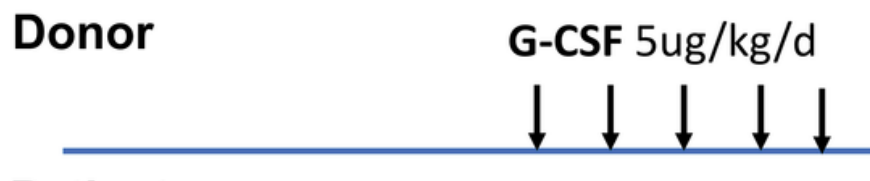

\section{Patient}

ATG $2.5 \mathrm{mg} / \mathrm{kg}$ qd

$\mid$ Bu $1 \mathrm{mg} / \mathrm{kg}$ q6h

-6and -5 Cy $14.5 \mathrm{mg} / \mathrm{kg}$ qd IVIG

FK506 0.01-0.03mg/kg.d cont inf MMF $0.5-0.6 \mathrm{~g} / \mathrm{m}^{2} \cdot \mathrm{d}$ q12h



$\downarrow$

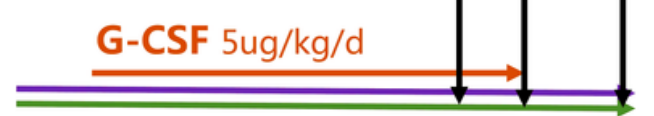

$\begin{array}{lllllllllllllllllllllll}-9 & -8 & -7 & -6 & -5 & -4 & -3 & -2 & -1 & 01 & +1 & +2 & +3 & +4 & +5 & +6 & +7 & +8 & +9 & +10 & +11 & +21 & +31\end{array}$

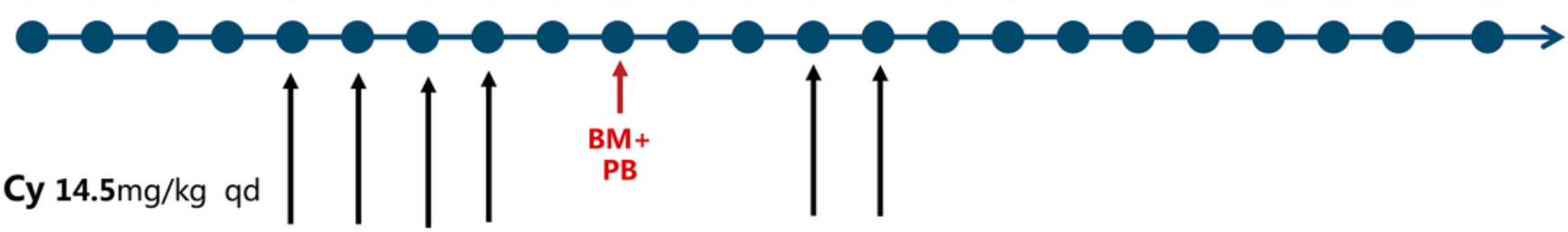

Flu $35 \mathrm{mg} / \mathrm{m}^{2} \cdot \mathrm{d}$ qd

CTX $50 \mathrm{mg} / \mathrm{kg} \cdot \mathrm{d}$

Figure 1

Conditioning regimens for patients with NCL. ATG indicates antithymoglobulin; BM, bone marrow; Bu, busulfan; Cy/CTX, cyclophosphamide; Flu, flurabine; MMF, mycophenolate mofetil; PB, peripheral blood stem cell; FK506, tacrolimus; IVIG, human immunoglobulin for intravenous injection; G-CSF, Granulocyte colony stimulating factor.
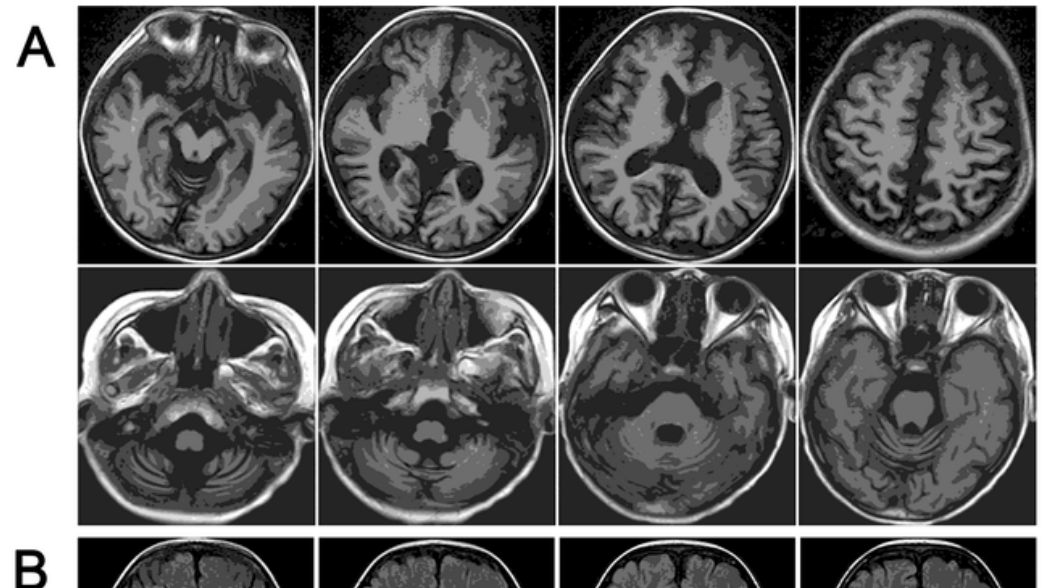

B

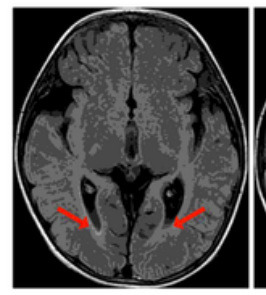

C

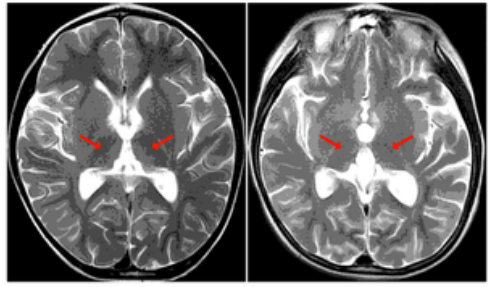

D
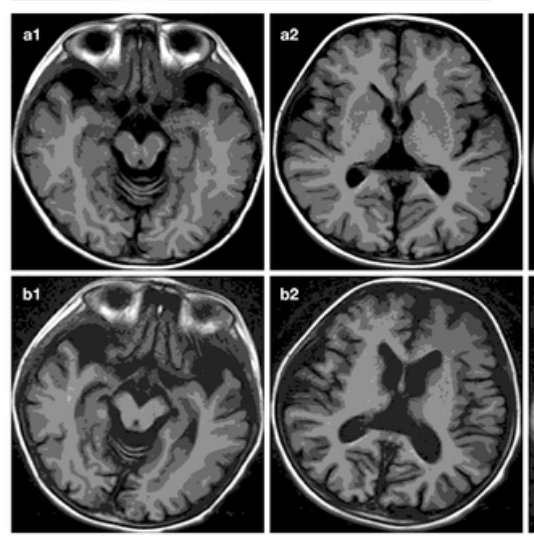
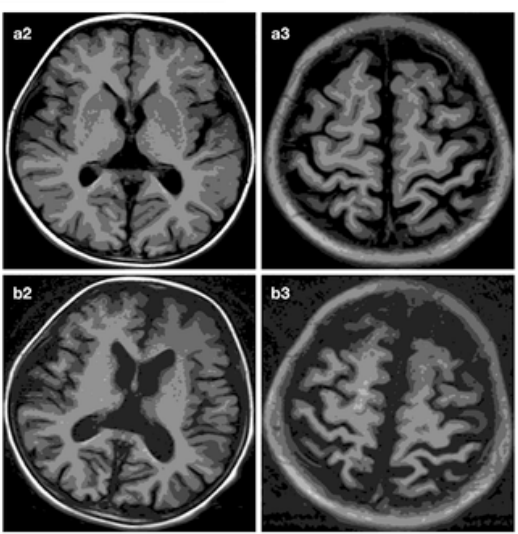

Figure 2

Representative images of abnormal brain MRI in patients. A. T1WI shows the diffuse atrophy of cerebrum and cerebellum, thinned cortex, prominent sulci and enlarged ventricles. B. T2-FLAIR shows bilateral periventricular hyper-intensity (red arrows). C. T2WI shows mild low signal of bilateral thalami (red arrows). D. Brain atrophy progression. T1WI from baseline MRI shows cerebral atrophy (a1, a2, a3). 